\title{
Teknologi Pembuatan Lateks Dadih Melalui Proses Penggetaran
}

\section{(The Preparation Technology of Creamed Latex by Vibration Process)}

\author{
Yasinta $^{1)}$, Rachmad Edison ${ }^{2)}$, Maryanti $^{2{ }^{*}}$ \\ 1) Program Studi Produksi dan Manajemen Industri Perkebunan, Jurusan Budidaya Tanaman \\ Perkebunan, Politeknik Negeri Lampung dan ${ }^{2)}$ Jurusan Budidaya Tanaman Perkebunan, \\ Politeknik Negeri Lampung. Jl. Soekarno-Hatta No. 10 Rajabasa, Bandar Lampung, Telp (0721) \\ 703995 Fax : (0721) 787309 \\ E-mail: yasinta.20@yahoo.com
}

\begin{abstract}
Obstacles factor to get natural rubber raw materials is less efficient for latex processing into concentrated latex, because it need a long time that 2-3 weeks. Centrifugation method many used by concentrated latex factory because it can concentrate the latex with a short relatively time. While the weakness of the centrifugation method is more expensive if that compared with the curdling. With the weakness centrifugation method and curdling, in this research, making the concentrated latex are used vibration method, with the addition of curdle. The purpose of this research is to get the optimum vibrations speed for the concentrated latex manufactured, the speed of the vibrations are used $150 \mathrm{rpm}, 175 \mathrm{rpm}$, $200 \mathrm{rpm}, 225 \mathrm{rpm}$ and $250 \mathrm{rpm}$. The design are used in this research is Randomized Block Design with 6 treatments was repeated 4 times, then obtained 24 units of the experiment, if there is a real difference, then used the BNT at the level of 5\% and the data analysis process using Minitab version 16. the most optimum RPM are used in this research is 225 with a quality approaching the standard.
\end{abstract}

Keywords: latex, concentrated latex, vibration, $\mathrm{cmc}$

DOI: http://dx.doi.org/10.25181/jaip.v7i1.906

Diterima: 1 Desember 2018 / Disetujui: 20 Maret 2019 / Diterbitkan: 18 Mei 2019

\section{PENDAHULUAN}

Lateks pekat merupakan produk olahan lateks alam yang dipekatkan dengan proses sentifugasi atau pendadihan dari Kadar Karet Kering (KKK) 28-30\% menjadi KKK 60-64\%. Biasanya lateks pekat digunakan untuk pembuatan bahan-bahan karet yang tipis dan bermutu tinggi. Masalah yang dihadapi produsen saat ini adalah sulit memperoleh bahan mentah karet alam yaitu lateks pekat. Hal ini terjadi karena sekitar $70 \%$ dari produsen karet alam adalah perkebunan rakyat yang sebelumnya hanya mengolah getah karet menjadi lump (gumpalan karet). Faktor lain yang menjadi hambatan untuk memperoleh bahan mentah karet alam adalah kurang efisiennya pengolahan lateks kebun menjadi lateks pekat.

Teknologi yang biasa digunakan dalam pembuatan lateks pekat adalah pendadihan dan sentrifugasi. Dalam pendadihan, kadar karet yang diperoleh cukup tinggi namun membutuhkan 
waktu yang lama sehingga untuk memproduksi dalam jumlah yang besar menjadi kurang efisien (Kurniasih, 2002). Waktu yang lama dalam proses pendadihan akan mempengaruhi pendapatan petani. Penelitian ini bertujuan untuk mendapatkan tingkat getaran terbaik pada mutu lateks pekat.

\section{METODE PENELITIAN}

Penelitian dilaksanakan di Laboratorium Analisis Politeknik Negeri Lampung dari bulan Desember 2016 sampai dengan bulan Oktober 2017. Alat dan bahan yang digunakan dalam penelitian ini dipisahkan menjadi beberapa kelompok. Alat dan bahan pembuatan lateks pekat yaitu shaker, pengaduk, ember, $\mathrm{pH}$ meter, timbangan analitik, saringan 40 mesh, termometer, beaker glass, erlenmeyer, pipit tetes, gelas ukur, dan hot plate, plastik, karet gelang, CMC, amoniak, dan aquadest. Alat dan bahan penentuan kadar karet kering yaitu timbangan analitik, gelas piala, pengaduk, gilingan lateks, oven, desikator, alat tulis, lateks pekat, dan asam formiat. Alat dan bahan penentuan $\mathrm{pH}$ lateks yaitu beaker glass, $\mathrm{pH}$ meter, alat tulis, lateks pekat, dan aquades. Alat dan bahan penentuan kadar jumlah padatan yaitu cawan, oven, desikator, gunting penjepit, pipet tetes, nampan, timbangan analitik, alat tulis, lateks pekat, dan aquades. Alat dan bahan penentuan waktu kemantapan mekanik yaitu erlenmeyer, hot plate, saringan 80 mesh, alat pengaduk listrik, beaker glass, pengaduk, alat tulis, thermometer, lates pekat, dan amoniak.

Rancangan yang digunakan dalam penelitian ini adalah Rancangan Acak Kelompok (RAK) dengan 6 perlakuan yaitu $\mathrm{L}_{1}=$ kontrol (tanpa getaran); $\mathrm{L}_{2}=$ getaran $150 \mathrm{rpm}$; $\mathrm{L}_{3}=$ getaran $175 \mathrm{rpm}$; $\mathrm{L}_{4}=$ getaran $200 \mathrm{rpm} ; \mathrm{L}_{5}=$ getaran $225 \mathrm{rpm}$; dan $\mathrm{L}_{6}=$ getaran $250 \mathrm{rpm}$. Masing-masing perlakuan diulang sebanyak 4 kali sehingga terdapat 24 satuan percobaan. Analisis data dilakukan dengan analisis ragam dan apabila terdapat perbedaan nyata, selanjutnya untuk mengetahui beda rata-rata perlakuan terhadap variabel yang diamati digunakan uji BNT pada taraf 5\% dan proses analisis data menggunakan Minitab versi 16. Mutu lateks pekat sesuai ISO 2004 yang diamati adalah kadar karet kering, pH, kadar jumlah padatan, dan waktu kemantapan mekanis (MST).

\section{Proses Pembuatan Lateks Dadih}

Lateks yang diperoleh dari kebun diberi amoniak dengan dosis $60 \mathrm{ml} . \mathrm{liter}^{-1}$ dan konsentrasi $25 \%$. Setelah itu aquades sebanyak $8,75 \mathrm{ml}$ yang sudah dipanaskan pada suhu $75^{\circ} \mathrm{C}$ dituangkan dalam beaker glass $250 \mathrm{ml}$ yang sudah terdapat CMC sebanyak 0,23\% dan diaduk hingga homogen. Selanjutnya campuran CMC dan aquades yang sudah homogen ditambahkan lateks sebanyak $250 \mathrm{ml}$. Setelah itu aduk hingga rata kemudian ditutup menggunakan plastik dan diikat dengan karet gelang hingga rapat. Untuk perlakuan kontrol lateks hanya didiamkan selama 14 hari dan untuk perlakuan penggetaran lateks dimasukan ke dalam shaker, diatur sesuai dengan perlakuan dan dibiarkan sampai 39 jam. Setelah itu alat dimatikan dan lateks didiamkan selama 4 hari. 


\section{HASIL DAN PEMBAHASAN}

\section{Kondisi Lateks Sebelum Perlakuan}

Sebelum dilakukan perlakuan lateks terlebih dahulu diukur pH serta Kadar Karet Kering (KKK) untuk mengetahui kondisi lateks sebelum perlakuan. Hasil pengukuran yang didapatkan dapat dilihat pada Tabel 1.

Tabel 1. Hasil pengukuran pH dan KKK lateks awal

\begin{tabular}{lccc}
\hline No & Perlakuan & $\mathrm{pH}$ & Kadar Karet Kering (KKK) \\
\hline 1 & Kontrol (Pendadihan) & 6,63 & 26 \\
2 & $150 \mathrm{rpm}$ & 6,41 & 22 \\
3 & $175 \mathrm{rpm}$ & 6,53 & 24 \\
4 & $200 \mathrm{rpm}$ & 6,57 & 27 \\
5 & $225 \mathrm{rpm}$ & 6,71 & 28 \\
6 & $250 \mathrm{rpm}$ & 6,40 & 21 \\
\hline
\end{tabular}

Pada Tabel 1 terlihat bahwa lateks yang digunakan pada penelitian ini memiliki $\mathrm{pH}$ dan KKK yang kurang baik. $\mathrm{pH}$ lateks segar yang baik berada pada kisaran 6,8 -7 karena pada kisaran $\mathrm{pH}$ tersebut lateks bersifat stabil dan tidak akan menggumpal (Purbaya \& Suwardin, 2017).

\section{Pengaruh Getaran pada pH Lateks Pekat}

Hasil sidik ragam menunjukan bahwa perlakuan getaran dengan berbagai rpm tidak berpengaruh pada $\mathrm{pH}$ (Tabel 2). Nilai $\mathrm{pH}$ yang didapatkan untuk semua perlakuan tidak memenuhi standar mutu ISO 2004 yaitu 10,8-11,8. Hasil percobaan yang dilakukan tidak berbeda nyata jika dibandingkan dengan kontrol.

Penurunan $\mathrm{pH}$ terjadi karena terbentuknya asam hasil penguraian oleh bakteri. Apabila lateks ditambahkan dengan asam akan terjadi penurunan $\mathrm{pH}$ sampai pada titik isoelektrik sehingga partikel karet menjadi tidak bermuatan. Protein pada lateks yang kehilangan muatan akan mengalami denaturasi sehingga selubung protein yang berfungsi melindungi partikel karet akan terjadi tumbukan yang menyebabkan terjadinya koagulasi. Koagulasi akan terjadi di daerah dimana potensial tidak mantap (stabil) yang dinamakan daerah potensial stabilitas kritis yaitu dengan $\mathrm{pH}$ sekitar 3,7 sampai 5,5 (Ali et al., 2010). 
Tabel 2. Uji nilai tengah pengaruh getaran terhadap $\mathrm{pH}$ lateks pekat

\begin{tabular}{lrr}
\hline No & Perlakuan & $\mathrm{pH}$ \\
\hline 1 & Kontrol (pendadihan) & $10.63 \mathrm{a}$ \\
2 & $150 \mathrm{rpm}$ & $10.49 \mathrm{a}$ \\
3 & $175 \mathrm{rpm}$ & $10.35 \mathrm{a}$ \\
4 & $200 \mathrm{rpm}$ & $10.46 \mathrm{a}$ \\
5 & $225 \mathrm{rpm}$ & $10.45 \mathrm{a}$ \\
6 & $250 \mathrm{rpm}$ & $10.66 \mathrm{a}$
\end{tabular}

Keterangan: Angka pada kolom yang diikuti dengan huruf yang sama menunjukkan tidak berbeda (non significant)

\section{Pengaruh Getaran pada Kadar Karet Kering (KKK) Lateks Pekat}

Hasil sidik ragam menunjukkan bahwa perlakuan getaran dengan berbagai rpm bengaruh nyata pada kadar karet kering yang dihasilkan yang dapat dilihat pada Tabel 3. Berdasarkan Tabel 3 bahwa lateks yang digetarkan tidak mencapai standar mutu lateks pekat ISO 2004 yaitu $64 \%$.

Tabel 3. Uji nilai tengah pengaruh getaran terhadap KKK lateks pekat

\begin{tabular}{lcc}
\hline No & Perlakuan & KKK $(\%)$ \\
\hline 1 & Kontrol (pendadihan) & $56 \quad \mathrm{~b}$ \\
2 & $150 \mathrm{rpm}$ & $40,75 \mathrm{a}$ \\
3 & $175 \mathrm{rpm}$ & $43,25 \mathrm{a}$ \\
4 & $56 \quad \mathrm{~b}$ \\
5 & $200 \mathrm{rpm}$ & $57,25 \mathrm{~b}$ \\
6 & $225 \mathrm{rpm}$ & $40,75 \mathrm{a}$
\end{tabular}

Keterangan: Angka pada kolom yang diikut dengan huruf yang sama menunjukkan tidak berbeda (non significant)

Kadar karet kering awal merupakan salah satu faktor yang mempengaruhi mutu lateks pekat, karena KKK awal yang digunakan pada penelitian ini kurang baik. Hal ini sejalan pada penelitian Susanto \& Nurhayati (2017), faktor-faktor yang mempengaruhi mutu lateks sentrifugasi adalah pengawetan lateks kebun, KKK lateks kebun, pengendapan lateks kebun, penambahan sabun amoniumlaurat sebelum ataupun sesudah pemusingan, pengangkutan, dan cara pengambilan sempel lateks pekat. Selain itu terdapat faktor lain mengapa KKK lateks pekat rendah.

Menurut Maspanger (2007), kecepatan sentrifugasi dan lama pemeraman berpengaruh terhadap perolehan KKK lateks dadih. Semakin lama pemeraman dan makin tinggi kecepatan 
sentrifugasi maka akan makin tinggi KKK lateks dadih yang dihasilkan. Semakin lama pemeraman dan makin tinggi kecepatan sentrifugasi maka akan makin tinggi KKK lateks dadih yang dihasilkan. Hal yang sama didapatkan pada penelitian Krisnawati (2014), KKK yang rendah juga dipengaruhi oleh efisien mesin sentrifugasi pengolahan lateks kebun menjadi lateks pekat yang rendah, akibatnya tidak dapat memisahkan karet dengan air dalam lateks dengan optimal.

Menurut Pristiyanti (2006) semakin tinggi kadar karet dalam lateks berarti jarak antar molekul karet dalam lateks semakin dekat dan jumlah air dalam lateks semakin sedikit sedangkan semakin rendah kadar karet dalam lateks berarti jumlah air dalam lateks semakin banyak dan jarak antar molekul karet dalam lateks semakin jauh.

\section{Pengaruh Getaran pada Kadar Jumlah Padatan (KJP) Lateks Pekat}

Hasil sidik ragam menunjukkan bahwa perlakuan getaran berpengaruh pada kadar jumlah padatan dan selanjutnya dilakukan uji nilai tengah BNT pada taraf kepercayaan 5\% dapat dilihat pada Tabel 4 kadar jumlah padatan tertinggi didapatkan pada perlakuan $225 \mathrm{rpm}$ yaitu 58,75, selanjutnya diikuti dengan perlakuan $200 \mathrm{rpm}$, kontrol, $175 \mathrm{rpm}, 250 \mathrm{rpm}$ dan paling terendah yaitu 150 rpm yaitu 41,5. Berdasarkan Tabel 4 bahwa nilai kadar jumlah padatan yang didapatkan untuk semua perlakuan tidak memenuhi standar mutu ISO 2004 yaitu 66\%.

Tabel 4. Uji nilai tengah pengaruh getaran terhadap kadar jumlah padatan lateks pekat

\begin{tabular}{lrr}
\hline No & Perlakuan & Kadar jumlah padatan (\%) \\
\hline 1 & Kontrol (pendadihan) & 57,5 b \\
2 & $150 \mathrm{rpm}$ & $41,5 \quad \mathrm{a}$ \\
3 & $175 \mathrm{rpm}$ & $44,75 \mathrm{a}$ \\
4 & $200 \mathrm{rpm}$ & $57,75 \mathrm{~b}$ \\
5 & $225 \mathrm{rpm}$ & $58,75 \mathrm{~b}$ \\
6 & $250 \mathrm{rpm}$ & 42,25 a
\end{tabular}

Keterangan: Angka pada kolom yang diikuti dengan huruf yang sama menunjukan tidak berbeda (non significant)

Pengukuran KJP bertujuan untuk mengetahui jumlah padatan yang terdapat dalam lateks, baik berupa partikel karet maupun bahan bukan karet lainnya (Juniarti, 2008). Kadar karet kering awal merupakan salah satu faktor yang mempengaruhi mutu lateks pekat, karena KKK awal yang digunakan pada penelitian ini kurang baik, nilai KKK yang rendah menyebabkan KJP yang rendah. Nilai KKK yang didapat lebih kecil dari nilai KJP.

Hal ini sejalan dengan penelitian Juniarti (2008), Nilai KKK yang selalu lebih kecil dari nilai KJP ini dikarenakan dalam perhitungan KKK yang diihitung hanya komponen karet dalam 
lateks sedangkan KJP memperhitungkan semua padatan, baik komponen karet maupun komponen bukan karet yang ada di dalam lateks (sekitar 2\%). Komponen bukan karet meliputi partikel dalam fraksi frey wyssling (karotenoid dan lipid), partikel lutoid dalam fraksi bawah, serta karbohidrat dan inositol dalam fraksi serum, hanya air dalam fraksi serum yang tidak dihitung.

Nilai KJP yang memenuhi standar mutu lateks pekat berpengaruh terhadap hasil barang jadi karet yang dihasilkan, standar mutu lateks pekat yaitu 66\%. Menurut Dalimunthe (2008) Kadar KJP pada lateks pekat sangat berpengaruh pada kekuatan tarik benang karet yang dihasilkan. Lateks dengan KJP yang tinggi, akan menghasilkan benang karet dengan kekuatan tarik yang semakin besar. Sedangkan bila KJP rendah, benang karet yang dihasilkan akan mudah koyak dan melar bila ditarik, sehingga perlu adanya penetapan kandungan KJP lateks pekat yang sesuai dan baik.

\section{Pengaruh Getaran pada Waktu Kemantapan Mekanik (MST) Lateks Pekat}

Hasil sidik ragam menunjukan bahwa perlakuan getaran berpengaruh nyata pada waktu kemantapan mekanik, dan selanjutnya dilakukan pengujian nilai tengah menggunakan BNT pada taraf kepercayaan 5\%. Dapat dilihat pada Tabel 5 waktu kemantapan mekanik tertinggi didapatkan pada perlakuan $250 \mathrm{rpm}$ yaitu 1010,75 selanjutnya diikuti dengan perlakuan $225 \mathrm{rpm}, 200 \mathrm{rpm}, 150$ rpm, kontrol dan yang terendah pada perlakuan 175 rpm yaitu 882,2. Berdasarkan Tabel 5 bahwa nilai waktu kemantapan mekanik yang didapatkan untuk semua perlakuan memenuhi standar mutu ISO 2004 yaitu minimal 450 detik.

Tabel 5. Uji nilai tengah pengaruh getaran terhadap waktu kemantapan mekanis lateks pekat.

\begin{tabular}{crrr}
\hline No & Perlakuan & Waktu kemantapan mekanis (detik) \\
\hline 1 & Kontrol (pendadihan) & 885 & a \\
2 & $150 \mathrm{rpm}$ & 933 & $\mathrm{ab}$ \\
3 & $175 \mathrm{rpm}$ & 882,2 & $\mathrm{a}$ \\
4 & $200 \mathrm{rpm}$ & 980 & $\mathrm{bc}$ \\
5 & $225 \mathrm{rpm}$ & 1006,2 & $\mathrm{c}$ \\
6 & $250 \mathrm{rpm}$ & 1010,7 & $\mathrm{c}$
\end{tabular}

Keterangan: Angka pada kolom yang diikuti dengan huruf yang sama menunjukan tidak berbeda (non significant)

Dapat dilihat pada Tabel 5 waktu kemantapan mekanik yang dimiliki lateks pekat baik karena melebihi batas minimum standar mutu lateks pekat, dengan nilai MST yang tinggi maka lateks akan tahan terhadap guncangan atau pengadukan yaitu tahan terhadap penggumpalan. 
Menurut Dhalimunthe (2008), waktu kemantapan mekanik menunjukan waktu ketahanan lateks terhadap pengaruh mekanik (misal pengadukan), seperti ketahanan untuk menggumpal (koagulasi). Hal ini sejalan dengan penelitian Nurhayati \& Andayani (2015) yang menyatakan bahwa waktu kemantapan mekanik merupakan besaran yang mencerminkan ketahanan koloid lateks, terhadap gaya mekanis yang diberikan kepadanya karena gaya mekanis tersebut dapat merusak partikel karet.

\section{KESIMPULAN DAN SARAN}

\section{Kesimpulan}

Dari hasil penelitian dapat disimpulkan bahwa penggetaran optimum untuk pembuatan lateks pekat terdapat pada getaran $225 \mathrm{rpm}$ dengan nilai $\mathrm{pH}$, kadar karet kering, dan kadar jumlah padatan tidak memenuhi standar dengan nilai berturut-turut sebesar 10,45, 57,25 dan 58,75. Sedangkan nilai waktu kemantapan mekanik memenuhi standar mutu yaitu 1006,2.

\section{Saran}

Perlu dilakukan penelitian tentang proses penggetaran dengan rpm yang lebih tinggi atau cara pengetarannya berbentuk vertikal.

\section{DAFTAR PUSTAKA}

Ali, F., Sihombing, A., \& Fauzi, A. (2010). Koagulasi lateks dengan ekstrak gadung (Dioscorea hispida Dennts). Jurnal Teknik Kimia, 17(3), 8-16.

Dalimunthe, V. H. Penentuan Kandungan Padatan Total (\% TSC) Lateks Pekat dan Pengaruhnya Terhadap Kekuatan Tarik Benang Karet di PT. IKN-Medan.

Darmawan, N., Fitrianti, F., \& Dewi, I. R. (2017, November). Lateks karet alam bebas protein menggunakan natrium hidroksida. In Prosiding Seminar Nasional Kulit, Karet dan Plastik (Vol. 6, No. 1).

Juniarti, D. (2008). Teknologi Proses Pencangkokan Akrilat Pada Karet Alam Menggunakan Inisiator Hidrogen Peroksida. Skripsi. Institut Pertanian Bogor. Bogor.

Krisnawati. (2014). Kopolimerisasi Cangkok Stirena dan Metil Metakrilat pada Lateks Karet Alam Berpotensi Rendah. Skripsi. Institut Pertanian Bogor. Bogor.

Kurniasih, N. (2002). Efisiensi Pemekatan Lateks Dengan Metode Sentifugasi. Skripsi. Institut Pertanian Bogor. Bogor.

Maspanger, D. R. (2007). Pembuatan lateks dadih dengan proses sentrifugasi putaran rendah dan kualitas barang jadi karetnya. Agritech, 27(3), 124-129. 
Nurhayati, C., \& Andayani, O. (2015). Pengolahan lateks pekat proses dadih menggunakan garam alginat hasil ekstraksi rumput laut untuk produk busa. Jurnal Dinamika Penelitian Industri, 26(1), 49-58.

Prastanto, H., Falaah, A. F., \& Maspanger, D. R. (2014). Pemekatan lateks kebun secara cepat dengan proses sentrifugasi putaran rendah. Jurnal Penelitian Karet, 32(2), 181-188.

Purbaya, M., \& Suwardin, D. (2017). Pengujian kualitatif terhadap jenis koagulan dalam bahan olah karet. Indonesian Journal of Natural Rubber Research, 35(1), 103-114.

Santi, F., Restuhadi, F., \& Ibrahim, A. (2017). Potensi Ekstrak Kasar Enzim Bromelin pada Bonggol Nanas (Ananas comosus) Sebagai Koagulan Alami Lateks (Hevea brasiliensis). Jurnal Online Mahasiswa Fakultas Pertanian Universitas Riau, 4(1), 1-13.

Susanto, T., \& Nurhayati, C. (2017). Pengaruh temperatur dan waktu depolimerisasi lateks dadih terhadap penurunan berat molekul dan mutu lem karet. Jurnal Dinamika Penelitian Industri, 28(1), 32-41. 